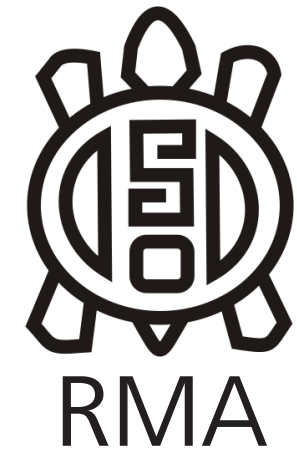

Dossier

\title{
O diabo da dúvida: histórias de pactos com o demônio no norte e no noroeste de Minas Gerais
}

\author{
Devil's doubt: stories of demoniac's pacts in the north and \\ northwest of Minas Gerais
}

Luzimar Paulo Pereira

Professor Adjunto do Departamento de Ciências Sociais, Instituto de Ciências Humanas, Universidade Federal de Juiz de Fora (UFJF). E-mail: mazinhop@gmail.com

\begin{abstract}
Resumo
As narrativas sobre pactos demoníacos são importantes tópicos da vida social dos violeiros do norte e noroeste de Minas Gerais. Por um lado, elas apresentam, passo a passo, as regras de consecução dos pactos, apontando os lugares, os momentos e os objetos mais adequados à sua execução. Verdadeiras "receitas", os relatos guardam todos os saberes relativos aos contatos com o diabo. Por outro lado, as narrativas também destacam o caráter supostamente factual dos eventos. Para todos os efeitos, as histórias tratariam de casos ocorridos com alguém, num lugar e numa época específica. Os relatos são eventos responsáveis por engendrar um campo de disputas específico onde os violeiros e seus aliados se enfrentam em torno de reputações. Quero argumentar que nesses embates em torno da "fama" de um tocador, a noção de "dúvida" é central. Não se trata de contestar a existência ou não do diabo. Nos relatos, o que está em questão é a veracidade do que se conta, medida não apenas pelo seu conteúdo substantivo mas também - e sobretudo - pela pessoa que fala ou de quem se fala.
\end{abstract}

Palavras-Chaves: sociedades camponesas; narrativas; reputação; pactos com o diabo

\begin{abstract}
The narratives about demonic pacts are an important topic in the social life of ten-string guitar players (violeiros) in North and Northwest of Minas Gerais. On the one hand, they present, step by step, the rules of how to achieve the pacts, pointing the places, the moments and the objects best suited for their execution. Like true "recipes", the reports keep all the knowledge concerning contacts with the devil. On the other hand, the narratives also highlight the supposedly factual nature of the events. For all intents and purposes, the stories are about cases that happened to someone, in a particular place and time. These reports are events which are responsible for engendering a particular battleground where ten-string guitar players (violeiros) and their allies face each other when dealing with reputations. I want to argue that the notion of "doubt" is central in these conflicts around the "fame" of a player. In the reports, the veracity of that account is central, measured not only by its substantive content but also - and above all - the person speaking or the person of spoken to.
\end{abstract}

Keywords: peasant societites; narratives; reputation; demoniac's pact

Explico ao senhor: o diabo vige dentro do homem, os crespos do homem - ou é o homem arruinado, ou o homem dos avessos. Solto, por si, cidadão, é que não tem diabo nenhum. Nenhum - é o que eu digo. O senhor aprova? (João Guimarães Rosa. Grande Sertão: Veredas)

As histórias sobre violeiros ${ }^{1}$ pactários são temas

\footnotetext{
1 "Violeiro" é o músico que toca a "viola" (ten strings guitar, em inglês), instrumento cordofônico composto por cinco pares de cordas. A "viola" desempenha papel central em festas religiosas tais como as folias e danças de São Gonçalo (Pereira 2011).
}

importantes nas conversas dos devotos católicos das regiões norte e noroeste do estado de Minas Gerais, Brasil. Em geral, as narrativas podem apresentar, passo a passo, as regras de consecução dos acordos demoníacos. Como pequenos manuais de conduta para futuros interessados, seriam respostas quase obrigatórias a uma pergunta específica: "mas, então, como se faz um pacto?". Verdadeiras "receitas" - para usar o termo nativo -, os relatos revelam um grande estoque de saberes relativos aos contatos com o diabo, colocando em jogo alguns dos conceitos centrais da vida religiosa dos devotos católicos da região. Por outro lado, as narrativas também podem destacar o 
caráter supostamente factual dos acordos demoníacos. São, portanto, histórias que tratam de acontecimentos que efetivamente ocorreram com alguém, em época e lugar específicos. Eventualmente, as "receitas" e os "causos" podem se confundir numa mesma história. Primeiro, quando o narrador apresenta as desventuras de um suposto pactário e acaba por ter que explicar como pôde ter sido realizado o acordo demoníaco. Ou, então, quando, ao fornecer uma "receita", nosso interlocutor usa o exemplo de algum tocador conhecido para descrever sua eficácia.

Num artigo anterior (Pereira 2012), eu argumentava que as narrativas de pacto colocam em jogo não apenas simples informações relevantes sobre a vida de um dado personagem da vida social. As histórias estão baseadas em ações pretensamente observadas que funcionam como ferramentas para conferir ou destruir reputações coletivas ou individuais. Sem apresentarem descontinuidades entre representações e ações, os relatos são eventos da linguagem responsáveis por atualizar o conhecimento demonológico das populações locais ao mesmo tempo em que propõem molduras (frames) sociais e cosmológicas, por meio das quais os tocadores são enquadrados e classificados pelos membros de uma determinada comunidade (Goffman 1975; ver também Comerford 2003).

Agentes importantes de concorridos rituais do catolicismo popular, os violeiros, de fato, são objeto constante do olhar perscrutador de ampla audiência. A atuação dos tocadores, o tratamento a eles dispensado ou a forma por meio das quais eles tratarão as demais pessoas, dependerá em grande parte do conhecimento que os outros têm a seu respeito, das suas condutas prévias, verdadeiras ou supostas, do seu status no seio das comunidades ou da comunidade de pertença comum. Previamente estabelecidas, as reputações também são construídas durante as interações. Como em outros domínios da vida coletiva de pequenas comunidades rurais, elas se perdem ou se ganham, precisam ser cuidadosamente preservadas ou buscadas a custo de muitas disputas (Marques 2002).

Nesse texto, procuro destacar um aspecto que me parece relevante para pensar os relatos sobre pactos demoníacos em suas conexões com as disputas por reputação. Nas lutas em torno de honras e graças (Pereira 2011), o tema da "dúvida" é central. As histórias de pacto estão sempre envoltas por atmosferas de suspeição. Não se trata, entretanto, de contestar a existência ou não do diabo. Nos relatos, o que está em questão é a veracidade do que se conta, medida não apenas pelo seu conteúdo substantivo mas também - e sobretudo - pela pessoa que fala ou de quem se fala. Num artigo considerado clássico, Lévi-Strauss (1998) destaca o papel da dúvida na feitiçaria nambiquara.
Escreve o autor:

\begin{abstract}
"Ter-se-iam, contudo, surpreendido bastante os céticos, invocando uma fraude tão verossímil, e da qual eles mesmos analisavam os móveis com bastante sutileza psicológica e senso político, para por em causa a boa fé e a eficácia de seu feiticeiro. Sem dúvida, ele não havia voado nas asas do trovão até o Rio Ananás, e tudo não passava de encenação. Mas essas coisas teriam podido se produzir, tinham-se efetivamente produzido em outras circunstâncias, elas permaneciam ao domínio da experiência. Que um feiticeiro mantenha relações íntimas com as forças sobrenaturais, isto é uma certeza; que, em tal caso particular, ele haja pretextado seu poder para simular uma atitude profana, isto é, domínio da conjetura e ocasião de aplicar a crítica histórica. O ponto importante é que as duas eventualidades não são mutuamente exclusivas, mais do que o é, para nós, a interpretação da guerra como o último sobressalto da independência nacional, ou como o resultado das maquinações dos negociantes de canhões. As duas explicações são logicamente incompatíveis, mas nós admitimos que uma ou outra possa ser verdadeira, segundo o caso; como são igualmente plausíveis, passamos facilmente de uma à outra, segundo a ocasião e o momento, e, para muitos, elas podem coexistir obscuramente na consciência" (1996: 198)
\end{abstract}

Os narradores e ouvintes das histórias de pactos do norte e noroeste de Minas Gerais concebem as possibilidades da existência de tocadores pactários e também do diabo. Ao mesmo tempo, sabem dos riscos das histórias serem mentirosas, isto é, inventadas para atingir negativamente a "fama" de um tocador. A elaboração da "experiência" considerada possível não anula a potencialidade de uma "crítica histórica", na medida em que um "causo" tido como verídico pode, na verdade, ser "invencionice" narrada apenas para prejudicar outra pessoa. O embate entre versões e contraversões dos relatos se organiza em torno da observação e interpretação de indícios ou sinais que atestem ou contestem o que se diz de um determinado tocador. A dúvida emerge, então, como inerente aos modos de relações que destacam as dimensões perceptíveis e imperceptíveis, narráveis e não-narráveis, da atividade de se tocar viola de dez cordas no norte e no noroeste mineiros. 


\section{Descrença}

Nos meus primeiros dias de campo no norte e noroeste mineiros, eu me deparei com algo intrigante. Quando impelidos a falar sobre o capeta, meus interlocutores se mostravam bastante arredios. Numa ocasião, perguntei sobre o diabo e dos supostos pactos que se pode fazer com ele a um dos tocadores de viola mais conhecidos do município de Arinos, MG. Sentado na varanda de sua casa, ele prontamente me respondeu: "Eu não acredito nele não. Tô mais é com minha mãezinha nossa senhora", dizia, voltando os olhos para o céu. "Com esse aí [o diabo]", ele continuava, "não quero nem conversa". Afastando com as mãos um diabo aparentemente imaginário ali presente, finalizava: "Saí pra lá, Coisa Ruim!".

A fala sintetiza algumas das minhas primeiras impressões sobre o tema dos pactos demoníacos. Entendi rapidamente que mencionar o nome de alguma entidade sagrada é, antes de tudo, um modo de evocar sua presença. A "fala", nesse sentido, tem um poder efetivo de presentificar ou chamar à presença aquele de quem se fala. Os católicos das regiões norte e noroeste de Minas, quando pronunciam o nome de algum dos seus santos devocionais, associam a ele expressões manuais de respeito: olhar para o céu, tirar o chapéu ou fazer o nome do pai. Trata-se, de fato, de um verdadeiro ritual, que conjuga expressões orais e atividades manuais. Para todos os efeitos, indicam que os santos podem estar por ali. Parecia-me, então, fácil entender a relutância dos meus interlocutores no caso dos assuntos demoníacos: se pronunciar o nome de uma personagem sagrada é um ato capaz de presentificá-la (ou de, pelo menos, clamar por sua presença), o receio de se falar do diabo teria uma explicação razoável ${ }^{2}$. Nenhum dos meus interlocutores pretendia atrair a entidade para perto de si.

O que me parecia mais difícil de compreender era outra coisa: se meus interlocutores diziam não "acreditar" no capeta, por que reforçavam, na fala e nos gestos, sua proximidade com os santos? Por que destacar a devoção a seres divinos quando não se está disposto a "crer" na existência do diabo? Demorei para entender que eu e alguns dos meus informantes não dizíamos a mesma coisa quando falávamos em "acreditar" em alguém ou alguma coisa. A expressão "não acreditar no diabo", no norte e noroeste de Minas Gerais, não evoca necessariamente um processo de secularização do pensamento religioso; nem é um simples reflexo dos (pouquíssimos e envergonhados) debates promovidos pela igreja católica oficial nos últimos dois séculos, responsáveis em grande medida por transformar pelo menos para seus principais ideólogos - o diabo

\footnotetext{
2 Significativamente, as pessoas preferem tratar o diabo por nomes genéricos ou apelidos, tais como o "cujo", o "dianho", a "coisa", o "diá", o "escuro", o "pé-de-bode" etc.
}

numa espécie de relíquia embaraçosa de um suposto cristianismo primitivo e supersticioso, uma metáfora, um símbolo tradicional ou uma simples abstração (Kolakowski 1987). Quando um violeiro me dizia "descreditar" no capeta, ele não estava querendo afirmar a inexistência da entidade. Tratava-se, na verdade, do uso cotidiano de um conceito muito específico de crença. A noção se aproximava, então, das ideias de "crédito" e "confiança"; não se restringindo o vocábulo, portanto, a levantar uma questão ontológica a respeito da existência, de fato ou não, da entidade religiosa. "Crer" ou "acreditar" é conferir crédito, é confiar no compromisso com o jogo mútuo dos dons e contradons (Mauss 2003). No norte e noroeste mineiros, afirmar a "descrença" no diabo era outra forma de dizer que não se quer "assunto" com ele, que devoto não pretende se engajar em contratos de reciprocidade com a entidade. Ao passo que o seu contrário - alardear a "crença" em deus ou nos santos católicos - era o mesmo que reafirmar uma lealdade e, conseqüentemente, desenhar uma espécie um círculo de giz, um limite de proteção, capaz de manter o anjo negro longe do fiel.

\section{llusão}

O receio faz todo o sentido. O demônio, caso nos descuidemos, pode se tornar uma criatura bastante presente em nossas vidas. Por isso, os homens também precisam estar preparados para enfrentá-lo, com perícia e sagacidade. Além de mal e poderoso, o diabo costuma ser muito esperto e sedutor. Exímio tocador de viola, o "tinhoso" pode aparecer disfarçado, empunhando seu instrumento sobre pequenas embarcações, com o intuito de encantar as mulheres que lavam suas roupas às margens dos rios. Manoel de Oliveira, da cidade de Urucuia, gosta de relatar um destes episódios fabulosos. Numa tarde, na varanda de sua casa, ele me contava esta história:

(...) fala que o capeta pegou uma canoa e desceu tocando uma viola. Tinha uma mulher na ponte, lavando a roupa e aí ouviu aquele som. E vai descendo, ouvindo aquela música, vai, vai, quando ela avistou aquela canoa com o violeiro. Evem, evem, e ela achando aquela música bonita. Quando chegou assim, perto dela, tinha um remanso e a canoa era um caco de cuia. E ele dentro tocando a viola. E aí, "Esse moço foi Deus que mandou" [disse ela]. "Não senhora, foi eu mesmo que vim" [respondeu o diabo]. "Esse moço veio lá do seu"[ela repetiu]. "Não senhora, eu vim lá de casa" [ele respondeu outra vez]. Aí, o menino [filho da mulher] falou: "Oi, o pé dele!". "Quieta, menino" [ela ralhou]. Aí, ele [o menino] não contente [disse]: "olha mãe, ele tem um chifre!". "Aquieta, 
menino! Cada qual como Deus o fez!". E aí ele [o demônio] falou: "É memo, dama, cada qual como fez o fez!" (Manoel de Oliveira, Urucuia/MG).

A história é até certo ponto exemplar. Em primeiro lugar, a narrativa tem início com a introdução de um verbo que distancia o narrador do relato apresentado. "Fala", que aqui quer dizer "o povo fala", indica que Manoel não se compromete ontologicamente com a história, deixando a avaliação de sua veracidade para o ouvinte de um relato produzido por uma coletividade de pessoas dispersa estrategicamente no tempo e no espaço. Não há menções a lugares ou épocas em que habitava o "povo" que criou a narrativa. O efeito deste distanciamento é ambíguo: se for "invenção", foi o "povo", enquanto o outro de Manoel, que "inventou". Logo, o narrador não estaria repassando "mentira" como se fosse verdade. Mas, por outro lado, se o "povo diz" pode ser que seja real. No norte e noroeste de Minas Gerais, como atesta o ditado, a voz do povo também pode ser a voz de deus; o que, noutros termos, revela a poder criativo de sua palavra.

A retórica que propõe o distanciamento está intimamente relacionada ao fato do "causo" tratar do extraordinário. Não apenas porque evoca uma personagem supostamente sobrenatural; afinal, para os habitantes do norte e do noroeste de Minas, o diabo pode ser tão cotidiano quanto os santos católicos. $\mathrm{Na}$ verdade, o extraordinário emerge do relato como capacidade que alguns agentes têm de realizarem feitos que os homens não podem ou não conseguem realizar. O mundo tem seus mistérios, mas não há registro, em Urucuia, terra de seu Manoel, de ser humano algum capaz de navegar em rios sobre um caco de cuia. Muito menos "tocando viola". No âmbito do extraordinário também há o "toque bonito" do capeta. Um toque que, evidentemente, não poderia ter origem entre os homens, mas apenas em "deus". O extraordinário desloca a existência cotidiana porque pode ser traduzido pela ideia de "milagre": acontecimento inusitado e estupendo que teve origem a partir da intervenção de forças divinas. No caso narrado, a questão que se torna relevante é o fato da mulher trocar a santidade de deus pela enganação do diabo. O demônio, o "Pai da Mentira", o operador maior de "falsos milagres", revelase, aqui, um grande ilusionista, um prestidigitador notável. O erro primordial da mulher foi atribuir à beleza extraordinária do toque diabólico aos poderes de deus. Erro que, inclusive, pode ser fatal. Em outras histórias que ouvi, diz-se que um dos efeitos do toque demoníaco é incitar as mulheres a saltarem nos rios - atraídas por eles - para depois morrerem afogadas.

No relato apresentado por seu Manoel, o diabo emite sinais da sua presença. Em certo sentido, mesmo o maior dos embusteiros pode ser desmascarado. Nada do que the é intrínseco deve escapar à percepção das pessoas, embora exija certas disposições específicas para seu entendimento. Primeiro, os sinais verbais. A narrativa nunca nos apresenta a música "bonita" que o demônio toca ${ }^{3}$. O que ouvimos na história, de fato, é a fala do capeta que, ao contrário da sua bela música, é extremamente seca e dura: "não senhora, eu vim lá de casa mesmo!" (Seu Manoel, quando narra, encena a entonação rude da fala do demônio). Além disso, o que diz o diabo também parece relevante como indício que revela sua identidade: sua fala nega a deus, sem nunca pronunciar seu nome (de deus). Se dizer o nome é evocar a presença, compreende-se também o receio do anjo negro. A graça do relato, por assim dizer, está contida no fim, quando o capeta diz: "não, dama, cada qual como fez o fez!", produzindo frase em que o sentido quase se perde apenas para que não seja pronunciado o nome de deus. O avesso aos sinais divinos é o indício da identidade do demônio.

Há também os sinais corporais. Os atributos distintivos do capeta aparecem para ambos, mulher e criança. No entanto, a mãe parece preferir não dar importância ao chifre e ao pé (rachado), enquanto o menino tenta insistentemente alertá-la sobre o que estes sinais devem significar. No artigo de 2012, eu havia dito que o separava a mulher e a criança era a capacidade do filho de enxergar os sinais demoníacos, contraposta a incapacidade da mãe. A força maligna do tentador residiria na sua habilidade de iludir e atrair as pessoas com pseudo-milagres; os quais só poderiam ser desvelados por sujeitos pios (como a criança) e piedosos (como os santos) (Pereira, 2012). Talvez, essa interpretação necessite ser mais matizada. A mulher percebe os chifres e o pé-rachado do capeta ("Aquieta, menino. Cada qual como deus o fez!"). O que ela não faz - ou se recusa a fazer - é confirmar esses traços corporais como indícios de que está na presença do diabo. A mãe percebe, mas não confirma o que os sinais nos dão a dizer. A narrativa evoca o tema do "encantamento", mas sem apelar para a capacidade dos seres demoníacos de escamotear sua essência a partir dos disfarces em sua aparência. O que parece estar em jogo é, na verdade, algo próximo à ideia de desejo. A mulher, noutros termos, não se importa com o que está vendo porque está literalmente atraída pelo diabo. Não seria nessa atitude o lugar semiótico de onde emerge o sentido nativo da "ilusão", que também é o outro nome do "amor" e do "sonho"?

\section{Receitas}

\footnotetext{
${ }^{3}$ É bom deixar claro que seu Manoel gostava de contar essa história antes de tocar uma música instrumental que ele mesmo compôs - o que, junto com a fala, acabava dando a ideia de que aquela era a música que o capeta poderia estar tocando.

${ }^{4}$ Ana Carneiro e María Rossi me chamaram a atenção para o fato de que a mulher soubesse que estava conversando com o capeta. Nesse sentido, a ideia de "ilusão" ganha sentidos mais próximos à ideia de "paixão".
} 
A rigor, os devotos da região norte e noroeste de Minas Gerais não utilizam os substantivos "pactário" e "pacto" para se referirem, respectivamente, a alguém comprometido com o demônio e ao acordo secreto firmado entre os dois. Mais comumente, eles preferem usar as locuções "aquele que tem parte com", ao invés do primeiro, e "tomar parte com", no lugar do segundo. As diferenças parecem significativas. A noção de "parte" evoca simultaneamente um contrato em que não existiria uma separação jurídica ou religiosa muito clara entre o contratado e o contratante, nem mesmo entre o que é dado e o que é recebido. Quando o devoto fala em "tomar parte" ele está querendo indicar, em primeiro lugar, a transmissão mágica de um certo poder ou qualidade do diabo ao pactário (esta qualidade é ela mesma denominada "parte"). Da mesma forma, aquilo que o interessado entrega ao demônio - pode ser a alma ou outro tipo de "favor" - também se confunde com seu proprietário. O pactário - aquele que "tem parte" - torna-se uma espécie de propriedade (temporária ou permanente) do seu parceiro de trocas, que passa a deter os direitos sobre aquilo que, antes, indicava sua ligação com deus (sua alma). Dessa maneira, ambos os lados se tornam "partes" um do outro, ao ocuparem uma "parte" específica no campo das disputas cósmicas (em oposição à "parte de deus", por exemplo).

A noção também designa, num sentido mais específico, uma espécie de acordo ilícito, obscuro, a partir do qual os contratantes se unem para uma "combinação", "tramóia" ou "conchavo"; o que explica, pelo menos parcialmente, o caráter secreto da operação. O conceito de "parte" se aproxima, aqui, das ideias de "estar à parte" ou "apartado", para indicar, por um lado, o afastamento do tocador das zonas mais próximas daquilo que é considerado central e mais importante na vida dos devotos da região, e, por outro, o seu caráter de conspiração e segredo. As narrativas sobre pactos e pactários, de um modo ou de outro, dramatizam o caráter secreto e ao mesmo tempo mágico das operações. Numa ocasião, quis saber de um tocador da Chapada Gaúcha, no noroeste de Minas Gerais, se existia essa história de tocador de viola que tem assunto com o diabo. Ele, então, me explicou:

O violeiro [pactário] é que qué tomá parte e ele não tem outro jeito de aprendê tocá. Aí ele vai tomá parte. Aí ele vai pruma igreja, na sexta-feira da paixão, à meianoite. Agora ele vai, diz que ele põe a mão no ocro da igreja lá5. Aí vem uma mão forte e aperta a mão dele, dessa pessoa que ta lá dentro da igreja e que qué aprender a tocar. Se ele grita, não aprende. E se ele não gritar, aprende. Agora depois que ele sai de lá, se ele não gritou, ele já sai um

\footnotetext{
${ }^{5} \mathrm{O}$ termo "ocro" designa um buraco ou passagem de ar aberto nas paredes de uma igreja.
}

mestre. A viola tem que ta encordoada, zerinha, desafinada (...). Ele não pode ter tocado nessa viola. Ele só pode ter comprado da loja, escolhido essa viola na loja, e trouxe, e ele vai tomar parte. Ele deixou desafinada e [depois que acabar o pacto], ele pega ela afinadinha (José Gonçalves Rocha, Chapada Gaúcha/MG).

Trata-se, aqui, de um relato que explica como se faz um pacto. Noutros termos, ele prescreve ao seu interlocutor - no caso, eu - uma "receita", um como fazer. Notemos, desde já, o cuidado que José toma logo na terceira frase do seu relato: "diz que ele põe a mão no ocro da igreja lá...". O "diz que", aqui, implica um afastamento da "receita", na medida em que autoriza o relato apelando para uma entidade anônima e coletiva ("o povo diz que..."). Compreensível. Saber e dizer a alguém como se faz um pacto é correr o risco de ser acusado de pactário também. Mais uma vez, o apelo a um narrador coletivo implica o descomprometimento público do contador com a história que ele contava.

A "receita" estabelece lugares e momentos propícios à sua realização: na meia-noite da Sexta-Feira da Paixão, diante de uma igreja. A data, permeada de ambiguidades (o dia em que Jesus sofreu no calvário é também a data das aparições de todos os tipos de encantados), é significativamente marcada por diversos tabus sexuais e alimentares, como a evitação de comer carne de gado ou de beber qualquer tipo de bebida alcoólica. O momento em que "este mundo" e o "outro mundo" se tornam perigosamente próximos é também o momento em que se pode tratar com o diabo. As presenças da igreja e do demônio, dentro dela, operam as inversões. A morada permanente de deus se transforma na habitação provisória do capeta. Os sinais da divindade são momentaneamente apropriados pela ação de forças malignas. Tudo, no mais sigiloso dos pactos que um homem faz, sozinho, com o diabo.

$\mathrm{Na}$ "receita" fornecida por José Gonçalves, assim como em outras, a viola desempenha papel fundamental. Segundo o relato, o pactário deverá levar o instrumento novo ou, pelo menos, recém-encordoado, mas sempre desafinado, para seu encontro com o capeta. A viola, noutros termos, precisa estar "virgem" do contato humano antes de ser empunhada pelo diabo. Ela precisa estar "pura". Nesse sentido, um dos efeitos do pacto inaugura um "novo" instrumento através de uma nova afinação (há versões que dizem que o diabo afina a viola diante do pactário, enquanto outras dizem que o pactário já vai pegá-la afinada). Em segundo lugar, as "receitas" trabalham com o tema das mãos. No relato apresentado pelo seu Zé Gonçalves, as mãos são apertadas de modo a causar dor no futuro violeiro. Numa outra versão, mais do que apertar, o diabo rasga a pele do pactário para quebrar seus ossos. Efetivamente, 
temos aqui também a ideia de reconstrução. Uma mão que se torna outra, assim como a viola que se tornou outra. Na versão alternativa da receita, parece até que uma mão (a do capeta) toma o lugar da outra (a do pactário), por dentro. Assim é que pode dizer que a "parte" vive "na mão" do tocador "por parte".

A receita de pacto parece implicar a criação de um duplo, constituído pela viola e o violeiro. Ambos se tomam amalgamados pela "parte do diabo". As dimensões do ouvir (saber afinar) e da mecânica das mãos (manipular o instrumento) definem as habilidades mais importantes do tocador, na medida em que são os meios pelos quais instrumento e pessoa tornam-se ajuntados, "uma coisa só". Não é por acaso que é nesse intervalo que se insere o poder maligno do capeta. Faltaria no relato de Seu Zé um outro elemento que reforça o par: os toques (ou músicas) de viola. O pactário não é apenas aquele que sabe afinar seu instrumento e demonstra habilidades com suas mãos. Ele também é capaz de executar músicas extraordinariamente belas. Outras "receitas" dão destaque a essa dimensão, quando afirmam que uma das responsabilidades do diabo é "ensinar" seus toques bonitos ao pactário. A ideia de "parte" ganha, então, novo significado. Ao se espalhar pelos corpos e espíritos dos violeiros, em seus ouvidos (para afinar), em suas mãos (para manipular) e nas suas "ideias" (para inventar toques), e ao se alojar na materialidade dos instrumentos (em suas cordas) para dar-lhes vida (as violas que respiram podem também tocar sozinhas), a força do pacto propõe uma totalidade que engloba a relação entre homens e coisas ao poder do diabo.

\section{Influência}

O conjunto de receitas de pacto pode ser contrastado com outro conjunto de relatos que denomino de narrativas da "influência". As histórias "de influência" explicam, para os próprios violeiros e para eventuais pesquisadores, como e porque eles começaram a tocar viola. No artigo de 2012, eu argumentava que o conceito de "influência" era aparentado da ideia de "dom": a habilidade, dada por deus ou herdada através da família, que permitia ao beneficiário ser exímio instrumentista (Pereira 2011; 2012). Nesse sentido, a noção expressaria a ideia geral de que é a própria divindade quem define a identidade musical de qualquer tocador (mesmo quando a influência é entendida como "familiar", no limite, ela é um presente divino dado a uma família). Em certo sentido, o conceito - ao modo holista de Louis Dumont - seria responsável por expandir o violeiro a outros planos de existência, estabelecendo conexões entre ele, seus familiares, seus antepassados e as divindades do céu (Dumont 1997).

No entanto, há uma outra dimensão da "influência" que precisa ser melhor trabalhada. Aquela que implica a ideia da ação. Apresento aqui o relato de seu Manoel, de Urucuia.

Olha, eu fui criado por uma mulher que tocava viola. Eu via ela tocar e achava muito bonito... Mas eu era muito pequeno e ficava só observando. Aí fui crescendo e ela saia e deixava a viola afinada e eu dei pra pegar a viola escondido. Daí, evai, com um tempo eu já saboia fazer uma coisinhas. Aí um dia ela pegou eu com a viola. Daí ela pegou e desafinou a viola. Falei: "e agora?". Aí, outro dia ela tornou a esquecer a viola afinada, eu peguei. Nisso, eu gravei a afinação. Aí, ela saia e eu lá esmerilhava, aprendendo as coisas que ela fazia. Cada vez que ela tocava eu pegava uma coisinha. Aí, quando é um dia, ela deixou a viola desafinada. Aí eu peguei e afinei a viola. Quando ela chegou eu tava tocando a viola. Ela falou: "quem que afinou essa viola procê?!". Eu falei: "foi eu". Aí, ela não mexeu mais comigo, não, largou, deixou...

Contado em primeira pessoa, como algo pertencente ao plano da experiência, o relato da influência destaca o esforço empreendido pelo proponente a tocador, ainda criança. Para diversos deles, de fato, aprender a tocar um instrumento é uma "peleja", uma luta, que o aprendiz tem contra o próprio instrumento, contra as limitações do seu corpo ("mãos") e espírito ("ideias"), além das próprias pessoas que se recusam a dividir sua viola com um menino. A peleja termina, efetivamente, quando o jovem aprendiz tem acesso total à viola. Quando é capaz de afiná-la e tocá-la diante de uma audiência. A questão, então, parece se constituir em torno das disposições que o conceito de influência quer abarcar: o impulso para se tocar viola e sua efetivação, quando aquele que quer consegue de fato aprender. "Porque é assim, né, tem aqueles que tem vontade de aprender pegar uma viola e sair tocando, mas não pode. Ele tem vontade, mas não tem influência".

Há, claro, um sentido de "dom" presente nos relatos da "influência". O violeiro que aprende está executando uma predisposição dada. No entanto, os relatos da influência também dramatizam as consequências dos esforços positivos dos próprios tocadores no sentido de aprender a tocar um instrumento. E são ainda mais: as histórias implicam o reconhecimento dessa "influência" por parte dos outros próximos que conseguem enxergá-la através de sinais indiscutíveis: saber afinar, fazer posições, reproduzir toques etc. Assim, o par estabelecido entre viola e violeiro se realiza, de um determinado ponto de vista, por meio do esforço do aprendiz que efetiva condição oferecida por deus na forma do "dom". Por outro lado, ele depende do reconhecimento dos outros. A lógica da "influência" 
operaria da mesma maneira dos sistemas de reputação: algo que se equilibra entre as visões das pessoas sobre si mesmo e as opiniões determinantes do coletivo a partir de seus atos (Bailey 1971)6.

Nesse sentido, o par viola e violeiro constituído nos termos da influência contrasta com o par estabelecido por meio de um pacto demoníaco. Nas narrativas da influência, a conexão constitui-se por meio do trabalho efetuado pelo futuro tocador cuja felicidade deve ser reconhecida pelos outros. No final do processo, a existência do "dom" é confirmada pela coletividade. Nos relatos de pacto, ao contrário, os sentidos da conexão são outros. O trabalho árduo do aprendizado longo tem como contraponto a dor de quem aprende de uma hora para outra (não deve ser por outra razão que os relatos sempre destacam que o pactário deve saber conter sua dor). Além disso, não há reconhecimento público do violeiro, apenas a operação secreta realizada em conluio entre homem e diabo. Ao invés da "peleja", o "sacrifício". Ao invés de dominar o instrumento, se é dominado por ele (a "parte" vive dentro da viola). Ao invés da honra e da graça, a desonra e a desgraça. Ao invés do reconhecimento público, o segredo. Como resultado, os sinais que identificam o tocador - o ouvido para afinar, a técnica manual para tocar, o conhecimento de uma variedade de toques - disparam sentidos opostos, para serem evidências da presença do diabo por detrás das operações. O que se dá a ver, efetivamente, é a mesma coisa: o par viola e violeiro. O que os une, no entanto, podem ser outras coisas bem diferentes.

\section{Fama}

Faustino de Jesus (nome fictício) tinha 70 anos quando fui visitá-lo em sua casa, numa tarde de janeiro de 2005. Agricultor aposentado, morava com a esposa e uma de suas filhas numa residência simples, localizada num bairro periférico do município de Chapada Gaúcha/MG. Simpático como quase todos os tocadores que conheci na região, o violeiro foi extremamente gentil durante os dois dias que estive ao seu lado. Como muitos tocadores da sua região, Faustino disse ter descoberto sua inclinação nas artes da viola ainda menino, pegando, às escondidas, o instrumento de seu irmão para tocar: "isso é da gente, uma inclinação que a gente tem". O violeiro disse também ter aprendido tudo o que sabe sozinho, observando e tentando imitar os tocadores mais consagrados da sua infância. O processo não foi fácil. Até ser reconhecido como tendo jeito para o instrumento, o então aprendiz tinha que se ver com as resistências do irmão, que não aceitava que uma criança mexesse na sua viola de estimação. Durante muito tempo, sua mãe Ihe serviu como aliada nestas

\footnotetext{
6 "A reputação de um homem", escreve Bailey, "é menos uma qualidade que ele possui do que as opiniões as quais outras pessoas têm sobre ele" (1971: 4).
}

situações. Dizia:

Eu com idade de uns oito anos aprendi. Tinha um irmão, mais velho, que era tocador. Ele ia pra roça, deixava a viola e eu panhava a viola é tocava, aí, ele não queria que pegasse na viola. Mas ele deixava afinada e eu falava pra minha mãe: "não conta pra ele não que ele vai bater em mim". Quando passou os dias, eu tocando, a velha achou bão, e eu tocando, e ela chego e contô pra ele. Ele foi olhando e eu toquei. Daí em diante ele deixava lá pra eu tocá (Faustino, Chapada Gaúcha/MG).

Faustino também não gostava muito de falar do diabo. O assunto, na verdade, parecia desagradá-lo profundamente: quando propus uma conversa rápida e genérica sobre o tema, disse não ter nada a ver com aquilo e ainda chamou sua esposa para que, na minha frente, confirmasse suas declarações:

Não... essa véia mesmo aí, ela doente, minha mulher, pode dizer: tenho parte nenhuma... Nem sei se conheço receita, não. Não sei. Tem um homem aí que diz que fez, eu nunca vi não. Não sei como é que faz.. Eu tenho um medo, menino. Peço pra deus livrar a gente (Faustino, Chapada Gaúcha/MG).

O velho Faustino não sabia, mas minha visita à sua residência foi realizada por conta dos rumores locais de que ele teria feito, anos atrás, o famigerado pacto com o diabo. Durante o período em que permaneci em Chapada Gaúcha, ouvi algumas versões sobre o assunto. Às vezes, os relatos surgiam com alguma naturalidade - logo depois de uma pergunta sobre o tema dos pactos - e proferidos com um indisfarçável ar de jocosidade. Noutras ocasiões, eles eram acompanhados por expressões de admiração, fazendo emergir aos poucos a imagem de um exímio instrumentista, capaz de pontear sua viola como ninguém e proprietário de um vasto repertório musical. Não faltavam às descrições também os toques do extraordinário, responsáveis por disseminar certo temor entre aqueles que acreditavam na sua condição de pactário: Faustino, diziam, seria capaz de fazer sua viola tocar sozinha e podia quebrar as cordas do instrumento de outro tocador através de rituais de magia.

As narrativas dos detratores não correspondiam em nada ao discurso elaborado pelo próprio Faustino. As lembranças dos seus esforços de aprendizagem, iniciados ainda na infância, se perdiam entre versões contrárias que destacavam as qualidades nefastas das suas habilidades instrumentais. Uma vez, outro cantador de Chapada Gaúcha, me dizia.

Tinha um homem que tinha parte. A 
mulher dele morreu agora esse ano. Ela contava a história todinha, que ele tinha parte, mas ninguém sabe como que ele aprendeu. Ele morava num sítio pequeno, folião de primeiro. Ele tocava a noite todinha e não voltava atrás [i.e., não repetia o toque]. (...) Muita gente conheceu ele tocá. Era mais especial do mundo. E ele dava pra quem ele queria a parte. Pra você pegá a parte com ele, ele tirava a corda da viola e botava na viola sua. Dali um mês cê tava tocando igual os caipira [i.e., os violeiros das duplas caipiras]. Ele dava aquela força lá. Cê misturava lá uma corda da viola dele e botava na viola sua e ficava as dez corda completa. Aí aprendia rapidinho, como aprendia muitos aqui. O Faustinho velho, lá da Chapada, aprendeu; ele não fala não. O Faustino é um tio meu, mas o Faustino tocava demais... (Cirilo [nome fictício], Chapada Gaúcha/MG).

Ao contrário das narrativas da influência, as histórias a respeito dos personagens supostamente pactários do norte e noroeste de Minas nunca me foram contadas pelos próprios tocadores. Aparentemente, não existe violeiro que se assuma como "tendo parte" com o diabo. Em geral, os relatos costumavam ser creditados ao povo ("É o povo que fala..."), muitas vezes pontuados pela expressão "diz que" ("Diz que fulano tem parte" $)^{7}$. Além disso, com bastante frequência, as narrativas me eram repassadas por interlocutores que, em sua maioria, diziam ter ouvido as histórias sobre pactos e pactários da boca de pessoas próximas. Ligados afetivamente àqueles com os quais eu conversava, os narradores "originais" dos relatos pareciam conferir a autenticidade das versões, ao serem apresentados como sujeitos de "confiança": um avô, um pai, um irmão, um compadre ou um amigo, a quem eles se referiam como incapazes de "mentir".

Meu pai viu o Belão tocá, não era mentira. O Belão tocava aqueles toque mais lindo daquele tempo, uma admiração, (...), diz que era bonito demais. Daí meu pai enchia o saco e ele [o Belão] falava: "agora cês entra lá pra dentro. E eu vou também lá

\footnotetext{
${ }^{7}$ Há semelhanças entre o "diz que" e o lo que diran espanhol, que também evoca um ator que julga sem piedade as pessoas e seus comportamentos. Diz Gilmore: "The audience here which determines his fate is ever watchful unforgiving, exacting. It is everyone and it is no one. Although the instigator may be known, no single tormentor can ever be identified, as no single admirer can; and indeed, people always say that it is el pueblo (the people) or the town which gossips or pillories or ostracizes or admires. The audience is a single, collective organism: the entire community acting as one. (...) Thus observed by everyone and by no one in particular, every man and woman conceives of him and hearself as being in a harsh spotlight, an actor in some unimaginable stressful drama, stretched out naked and helpeless for judgment before a tyranical judge, a nebulous, intangible, but everpresent taskmaster" (Gilmore 1987: 33).
}

pra dentro e vou deixar a viola tocando sozinha proceis vê". (...) Era noite isso. Aí todo mundo entrava pra dentro, ele também entrava, deixava a viola sozinha aqui e a viola ficava comendo cá fora. Verdade! A viola tocando sozinha! Tocava sozinha aquele mesmo toque que ele tocava com a mão aqui, a viola. Tinha alguém tocando, né? Ninguém via no escuro e o Belão tava lá dentro também. (...) Deve ser encanto, né? Porque tinha um compromisso com aquele anjo... (Jonas, Chapada Gaúcha-MG).

A insistência em atestar a veracidade das informações, recorrendo-se ao "povo" ou ao nome de pessoas consideradas idôneas, parece ser uma estratégica narrativa que revela a natureza não consensual dos relatos. Produtos de um campo de vozes discordantes, as histórias são disseminadas numa arena de disputas onde as reputações das pessoas e coletividades nunca são efetivamente rígidas ou imutáveis, estando sempre sujeitas aos movimentos diabólicos das opiniões e sociabilidades. No entanto, há que se considerar algumas diferenças. O uso da ideia de "povo" implica certo afastamento do narrador, que deixa a critério do ouvinte o julgamento da veracidade do que é contado. Em certa medida, o apelo evoca a tentativa de não se correr o risco de ser objeto de um tipo de avaliação moral que pode aproximar seu relato da "maledicência" (literalmente, dizer mal dos outros). A referência a nomes próprios que atestariam a veracidade do que se conta, portanto, é outra coisa. Ela aponta para a implicação do narrador na história. Na medida em que laços familiares são acionados, o contador informa que não há ambiguidade no que se conta. A história é efetivamente real. O nome de seus familiares atestam a veracidade do relato.

Não se trata aqui de lidar com versões de um mesmo "causo" transformado durante suas circulações por entre as pessoas. Há, efetivamente, duas narrativas diferentes em jogo: a do pacto e a da influência. Mais do que versões, ambas as modalidades de relatos permanecem como enquadramentos distintos que dão sentidos diferentes a sinais muitas vezes os mesmos. Os indícios do pacto não são inequívocos. A viola que toca sozinha, sinal da presença do diabo, pode, por outro lado, ter sido bolinada por algum bicho que passou sobre ela. É a "maldade das pessoas", a "inveja", que diz o contrário. A inversão de sentido não ocorre sem modificações das qualidades do próprio narrador das histórias. A "maldade" que se acusa ser atributo do tocador afamado desloca-se para a fala do disseminador das notícias. Nesse sentido, a narrativa pode soar como fofoca para atingir a reputação de quem se glosa. O relato perde valor de verdade para se tornar apenas a "fama" do violeiro. Numa ocasião, seu Manoel, de Urucuia, me falava do seu compadre, acusado de ser pactário do diabo. 
O compadre Aléscio (...), o povo fala que ele tocava por parte. Não tocava não! Dizem que ele botava a viola na mesa, e ela tocava sozinha. Mas é conversa. É só fama. Botaro essa fama nele, mas ele não fazia isso não. (...) [Ele] sabia tocá lundu, essas coisa. Então, tinha essa fama de violeiro [da parte]... Eu perguntei pros irmão dele se ele fazia isso: "Não, ele nunca fez isso não. É fama." (Manoel de Oliveira, Urucuia/MG).

Os embates por reputação ocorrem em torno da noção de "fama", que corresponde, grosso modo, à imagem pública do violeiro produzida pelas pessoas que o cercam. Num sentido amplo, o conceito opera no sentido de singularizar o tocador: o violeiro "afamado" é aquele que é conhecido por muita gente - por ser bom ou ruim. E quanto melhor ele for, mais "afamado" ele é. Resultado de avaliações coletivas, a fama evoca a pessoa moral (separada da sua existência física) que circula junto com as histórias de seus feitos e façanhas através da oralidade das outras pessoas (sobre a noção de "fama", ver Munn 1992). Ao mesmo tempo, a ideia também aponta para a suspeição temporária da veracidade de uma narrativa. Longe de ser incontestável, a reputação do violeiro passa a ser considerada "justa" ou "injusta", "verdadeira" ou "mentirosa". No reino da oralidade, a fama é disputada quando indícios físicos são testados e contestados oralmente pelos narradores das histórias ("a viola não toca sozinho nada. É bicho que passa por cima e o povo inventa").

Num primeiro momento, a noção de fama aponta para os perigos da excessiva diferenciação, quando um se torna "mais do que os outros" nas pequenas comunidades rurais do norte e noroeste mineiros ${ }^{8}$. No entanto, há um outro ponto a ser destacado. Os debates a respeito da biografia de um tocador parecem revelar a maneira pelas quais são constituídas e avaliadas as próprias práticas dos violeiros na região: se são os outros aqueles que (reconhecem) a influência, serão eles também quem poderão retirá-la. Cabe, neste sentido, garantir, através da luta, a autenticidade das opiniões gerais. O regime da dúvida é central nas histórias "de parte". Nesse sentido, o pacto não pode ser entendido apenas como rito que dramatizaria a venda individual da alma de um violeiro para o capeta. Muito ao contrário, ele pode ser outra coisa, para representar a consciência coletiva da usurpação social do espírito de um tocador.

Rio de Janeiro, 12 de Julho de 2016

\footnotetext{
${ }^{8}$ À primeira vista, as narrativas pareciam operar no sentido de reforçar a igualdade como um valor axiomático da vida comunitária. O pecado do suposto tocador da parte, por assim dizer, era ser considerado "melhor" instrumentista do que os demais violeiros de um lugar: "o povo falava", dizia um devoto, "porque ele era bão pra tocá. Os outros não fazia o que ele tocava, né?" (Augusto, Chapada Gaúcha/MG). O valor da igualdade em pequenas sociedades camponesas é registrado por diversos autores. Ver, por exemplo, Pitt-Rivers (1992).
}

\section{Agradecimentos}

Essse texto foi apresentado no I Seminário de Etnografia da Linguagem, realizado na Universidade Federal Fluminense, entre os dias 20 a 22 de outubro de 2015. O evento foi uma oportunidade de retomar texto já publicado em 201 (Pereira 2012) e rever abordagens e interpretações. Agradeço à Lucía Tennina e à Simone Silva pelo sucesso do encontro. Além delas, quero agredecer também os comentários sugestivos de Luciana Hartmann e dos demais colegas que participaram do Seminário, que muito contribuíram para minhas atuais reflexões. Obviamente, nenhum deles tem qualquer responsabilidade pelos eventuais equívocos desse artigo.

\section{Bibliografia}

Bailey, F.G.. (1971). Gifts and poison, Oxford, Basil Blackwell.

Campbell, J. K. (1988). "A honra e o diabo", in Peristiany, J. G. (Ed.), Honra e Vergonha: valores das sociedades mediterrâneas, pp. 111-126, Fundação Calouste Gulbenkian, Lisboa,

Comerford, J. (2003). Como uma familia: sociabilidade, territórios de parentesco e sindicalismo rural, Relume Dumará / Núcleo de Antropologia da Política/UFRJ, Rio de Janeiro.

Dumont, L. (1997). Homo Hierarchicus, Edusp, São Paulo.

Gilmore, D. (1987). Aggression and Community: Paradox of Andalusian Culture, Yale University Press, New Haven and London.

Goffman, E. (1975). Frame Analisys: an Essay on the Organization of Experience, Harvard University Press, Cambridge.

Kolakowski, L. (1987). "O Diabo", Enciclopédia EINAUDI, n. 12, pp. 243-265, Imprensa Nacional-Casa da Moeda, Lisboa.

Marques, A. C. (2002). Intrigas e Questões: vingança de família e tramas sociais no sertão de Pernambuco, Relume Dumará, Rio de Janeiro.

Mauss, M. (2003). Ensaios de Sociologia, Editora Cosac \& Naify, São Paulo.

Munn, N. (1992). The fame of Gawa: a symbolic study of value transformation in a Massim (Papua New Guinea) Society. Durham, London: Duke University Press.

Pereira, L. P. (2011). Os Giros do Sagrado: um estudo 
etnográfico sobre folias em Urucuia, MG, Editora 7Letras, Rio de Janeiro.

Pereira, L. P. (2012). "As vicissitudes da fama". Revista de Antropologia, v. 55, n. 2, pp. 1047-1083.

Pitt-Rivers, J. (1988). "Honra e posição social",
Peristiany, J. G. (Ed.), Honra e Vergonha: valores das sociedades mediterrâneas, pp. 12-59, Fundação Calouste Gulbenkian, Lisboa.

Pitt-Rivers, J. (1992). "El lugar de la gracia en la antropologia", in Pitt-Rivers, J. \& Peristiany, J.G. (Ed.), Honor y gracia, pp. 280-322, Alianza editorial, Madrid 